\title{
Normas para apresentação de trabalhos
}

A revista outra travessia aceita trabalhos inéditos de interesse voltado para literatura. A submissão dos textos deve seguir as chamadas de publicação lançadas duas vezes ao ano. Os trabalhos serão submetidos ao conselho de pareceristas da revista após breve análise da pertinência ao tema proposto e às normas de publicação. Eventuais sugestões de modificação ou revisão por parte do conselho consultivo serão comunicadas aos autores.

Os trabalhos devem ser enviados ao endereço de e-mail outratravessia@gmail.com respeitando as seguintes indicações:

- Os arquivos devem ser enviados com tamanho de página A4, fonte Garamond tamanho 12.

- O original não deve exceder 20 páginas e ser apresentado na seguinte sequência:

\section{Título do trabalho}

centralizado, tamanho 14, espaçamento 1,5.

Subtítulo (quando houver) centralizado, tamanho 12, espaçamento 1,5

Nome do autor (Instituição) Tamanho 12, alinhado à direita, espaçamento 1,5.

Resumo

Em português, tamanho 11, justificado, espaçamento 1,5. O resumo deve ter entre 100 a 200 palavras.

Palavras-chave: entre 3 e 5, separadas por ponto-e-vírgula 
Abstract (Résumé)

Em inglês ou francês, tamanho 11, justificado, espaçamento 1,5. O Abstract ou resumé deve ser a versão traduzida do resumo em português

Keywords: entre 3 e 5, separadas por ponto-e-vírgula

Texto. Fonte 12, espaçamento 1,5, justificado, com parágrafo em 1,25 centímetros.

As citações com 4 ou mais linhas devem ser separadas do texto por duas linhas, com recuo de 4 centímetros, fonte 10 , espaçamento simples.

As referências no corpo do artigo devem ser apresentadas em nota de rodapé respeitando o seguinte padrão: Sobrenome, Nome. Título da obra, ano, página. Aceitamos preferencialmente o sistema de citação por nota de rodapé.

\section{Referências}

Fonte 10, alinhadas à esquerda, espaçamento simples, com uma linha de espaço entre uma referência e outra. A apresentação das referências deve respeitar o seguinte padrão:

BENJAMIN, Walter. A modernidade e os modernos. Trad. Heindrun Krieger; Arlete de Brito e Tania Jatobá. $2^{a}$ ed. Rio de Janeiro: Tempo Brasileiro, 2000.

AGAMBEN, Giorgio. O que é o dispositivo? In: revista outra travessia, n. 05. Trad. Nilcéia Valdati. Florianópolis, 2005, p. 09-16. Disponível em: <http://www.periodicos.ufsc.br/index.php/Outra/article/ view/12576/11743>.

Ilustrações, quando houver, devem ser designadas como figuras, numeradas no texto (fig. 01, fig. 02) com título ou legenda abaixo da mesma.

Os trabalhos devem ser apresentados sem numeração de página.

Os autores terão direito a 2 exemplares da revista. 